\title{
EU food legislation impacts innovation in the area of plant-based dairy alternatives
}

Citation for published version (APA):

Leialohilani, A., \& de Boer, A. (2020). EU food legislation impacts innovation in the area of plant-based dairy alternatives. Trends in Food Science \& Technology, 104, 262-267.

https://doi.org/10.1016/j.tifs.2020.07.021

Document status and date:

Published: 01/10/2020

DOI:

https://doi.org/10.1016/j.tifs.2020.07.021

Document Version:

Publisher's PDF, also known as Version of record

Document license:

Taverne

Please check the document version of this publication:

- A submitted manuscript is the version of the article upon submission and before peer-review. There can be important differences between the submitted version and the official published version of record.

People interested in the research are advised to contact the author for the final version of the publication, or visit the DOI to the publisher's website.

- The final author version and the galley proof are versions of the publication after peer review.

- The final published version features the final layout of the paper including the volume, issue and page numbers.

Link to publication

\footnotetext{
General rights rights.

- You may freely distribute the URL identifying the publication in the public portal. please follow below link for the End User Agreement:

www.umlib.nl/taverne-license

Take down policy

If you believe that this document breaches copyright please contact us at:

repository@maastrichtuniversity.nl

providing details and we will investigate your claim.
}

Copyright and moral rights for the publications made accessible in the public portal are retained by the authors and/or other copyright owners and it is a condition of accessing publications that users recognise and abide by the legal requirements associated with these

- Users may download and print one copy of any publication from the public portal for the purpose of private study or research.

- You may not further distribute the material or use it for any profit-making activity or commercial gain

If the publication is distributed under the terms of Article $25 \mathrm{fa}$ of the Dutch Copyright Act, indicated by the "Taverne" license above, 
Commentary

\title{
EU food legislation impacts innovation in the area of plant-based dairy alternatives
}

\author{
Annisa Leialohilani ${ }^{\mathrm{a}, *}$, Alie de Boer ${ }^{\mathrm{b}}$ \\ ${ }^{\text {a } U p f i e l d ~ R e s e a r c h ~ a n d ~ D e v e l o p m e n t ~ B . V ., ~ t h e ~ N e t h e r l a n d s ~}$ \\ ${ }^{\mathrm{b}}$ Food Claims Centre Venlo, Campus Venlo, Maastricht University, the Netherlands
}

\section{A R T I C L E I N F O}

\section{Keywords}

European food law

Food innovation

Consumer protection

Dairy products

Plant-based

Dairy substitutes

Nondairy

\begin{abstract}
A B S T R A C T
Background: Dairy alternatives are foods that are made from plant-based milk instead of their usual animal products, such as cheese and yoghurt. Over the past few years, consumers increasingly choose to go dairy-free, which leads to a growth in available dairy alternatives product on the market. Although it is easiest for consumers to identify these products by the use of protected dairy terms ('yoghurt' or 'milk'), these protected terms may not be used by food business operators to designate their plant-based products.

Scope and approach: This article will examine the positive and negative impact of the EU regulatory framework on innovation in the dairy alternative industry and its consumers. Furthermore, potential solutions to overcome the identified barriers are explored.

Key findings and conclusions: The EU regulatory framework has positively affected innovation in the dairy alternatives industry by establishing legal clarity, and ensuring a high level of food safety and consumer protection. However, the same legislation negatively impacts innovation in the industry, namely due to: (i) the varying interpretation of the Regulation (EU) 1308/2013 (CMO); (ii) the different level of consumer protection between sectors; (iii) the absence of a legal definition of vegan food; and (iv) the narrow definition of 'milk' and 'milk products' as defined in the CMO. Either amending the definition of milk and milk products in the CMO, or expanding the list of exceptions to the definitions are identified as possible solutions to deal with the identified barriers.
\end{abstract}

\section{Introduction}

Dairy alternatives are plant-based milk and similar products such as cheese and yoghurt, that are made from plant-based milk instead of cow milk (Bailey, 2018). The innovative development and production of these dairy-free alternatives to food products that are traditionally animal-based, such as cheese from plant-based milk, was driven by the growing popularity of being dairy-free for both health and sustainability reasons (Bailey, 2018; Mäkinen, Wanhalinna, Zannini, \& Arendt, 2016; Röös, Garnett, Watz, \& Sjörs, 2018). It has been estimated that the global dairy-alternative milk market will grow to be $20 \%$ of the value of the dairy milk market in 2021 (Euromonitor International, 2017), which is exemplified by the increase in sales of Alpro's dairy alternative over $20 \%$ in 2014 in nine European countries (Strecker, 2016).

To protect consumers, both from unsafe substances and from misleading practices, different European food laws are developed to deal with specific composition and/or information requirements next to the General Food Law (GFL, Regulation (EC) No 178/2002) that lays down general principles and requirements for food (de Boer, 2019). One of these legal acts is Regulation (EU) No 1169/2011 on the provision of food information to consumers (also known as FIC), which obligates all food business operators to communicate the mandatory particulars (mandatory information, listed in Article 9) of every food product sold in the EU (European Parliament and Council, 2011). The first mandatory particular is the name or the 'sale description' of the food, defined as the name the product is sold under (Article 17 and Annex VII). This article also mentions that the name of a product must be its legal name, the name legally prescribed to a food product in Union provisions or Member State legislation. An example of such a legal name is 'butter', and thus to use such a name, a product must comply with the legal description of 'butter': solid, malleable emulsion, derived exclusively from milk with milk-fat content of at least $80 \% .{ }^{1}$ If no such legal name

\footnotetext{
* Corresponding author. Nassaukade 3, $3071 \mathrm{JL}$, Rotterdam, the Netherlands.

E-mail address: annisa.leialohilani@upfield.com (A. Leialohilani).

1 Appendix II of Regulation 1308/2013.
} 
exists, the name of the product must be its customary name, that is accepted and recognised by consumers within European Member States where the product is sold without needing further explanation (Article 2 (2)(o) FIC), such as 'fish fingers' in the UK (Food Standards Agency, 2014). If neither a legal name nor a customary name exist for a particular foodstuff, then the name of the product is required to be a descriptive name, such as 'macaroni in cheese sauce' (Department for Environment Food and Rural Affairs, 2017). This descriptive name describes the food, and if necessary its use, in such a way that consumers can know the 'true nature' of the product and are hereby enabled to distinguish this food from other comparable products (Food Standards Agency, 2014).

In the case of plant-based dairy alternatives, food business operators are not allowed to designate plant-based products with protected dairy terms, terms laid down in Annex VII of Regulation (EU) 1308/2013, also known as the CMO. In this paper, plant-based dairy alternatives are defined as plant-based products that substitute dairy products such as cheese, milk, cream and butter (Domke, 2018; Röös et al., 2018). This study analyses how this dairy terms-protection affects the dairy alternatives industry and their consumers, to provide further insights into how both the industry and legislators can respond to this growing product category. With previous research focussing on both nutritional quality as well as health considerations of plant-based dairy alternatives (Chalupa-Krebzdak, Long, \& Bohrer, 2018; Jeske, Zannini, \& Arendt, 2017; Munekata et al., 2020; Sousa \& Bolanz, 2017), this paper analyses how European legislation on dairy (terminology) affects the designation of plant-based dairy alternatives.

\section{Protection of dairy terms}

The organisation of the European single market for agricultural products is defined by Regulation (EU) 1308/2013 establishing a common organization of the markets in agricultural products, also known as the CMO. Annex VII of the CMO legally defines 'milk products' as products that are exclusively derived from milk, where 'milk' is further defined as the 'mammary secretion obtained from one or more milkings'. The CMO also prescribes that all dairy terms such as milk, butter, and yoghurt are exclusively reserved for milk and milk products (European Parliament and Council, 2013). Dairy alternative products therefore cannot be referred to with dairy-associated names (Bailey, 2018). Soy-based drinks for example are not allowed to be called 'soy milk' in the EU, as the product is not mammary secretion and this term is described on the list of exceptions under Commission Decision 2010/791/EU. However, in Australia for example, it is allowed to refer to these drinks as 'soy milk' (Sansone, 2017).

Products that do not fall within the CMO definition of a milk product may only use the protected designations if the name is listed under Commission Decision 2010/791/EU (European Parliament and Council, 2010). This Decision lists all the products that are exempted from protection in the CMO, and therefore these products can use the reserved dairy-related terminology in their names. Exempted products are categorised via the different EU Member States, that have approved exemptions in their national language. A specific term may therefore be authorised in one Member State and its official language, whilst its translation is not automatically allowed in other Member States. According to this Decision for example, 'lait d'amande' is allowed for use in France, but the English 'almond milk' is not allowed in the UK (European Parliament and Council, 2010).

In 2016, the Verband Sozialer Wettbewerb (VSW) brought the German food company, Tofu Town, to the Regional Court in Trier, Germany (Court of Justice of the European Union, 2017). The VSW, the German association for fair and social competition, ${ }^{2}$ believed Tofu Town had infringed the CMO's provisions on dairy terms protection. Tofu Town's

\footnotetext{
${ }^{2}$ Case C-422/16, at 15.
}

use of protected terms for milk products to designate their purely plant-based products such as 'rice cream spray', 'tofu butter', and 'veggie cheese', was believed to be misleading and therefore illegal by virtue of the CMO. The Regional Court however could not arrive at a final conclusion on this case: the Court had questions about the interpretation of Article 78 of the CMO (upon i.e. sales descriptions for certain sectors and products) in combination with CMO Part III, Annex VII, regarding the prohibition of dairy terms used by products that are not milk products as defined by the CMO. The German Court therefore requested the European Court of Justice (ECJ) for a preliminary ruling as well as answering three prejudicial questions regarding both the interpretation of Article 78 and point 1 and 2 of Part III, Annex VII of Regulation 1308/2013. These questions relate to whether or not these provisions can be interpreted as meaning that protected dairy terms can be used for purely plant based products, when the product name includes additional explanatory terms such as "soya" or "tofu".

For their initial argument, the German Court referred to a comparable case from $1998,{ }^{3}$ upon which the Court based their initial argument. This older case was case C-101/98. In this court case between the Union Deutsche Lebensmittelwerke GmbH (UDL) and the German Association against Unfair Business Practices (Schutzverband), the defendant was also accused of being in breach with European legislation ${ }^{4}$ on protected milk products. From 1987, before the CMO was established, dairy terms were legally protected by listing them in Council Regulation (EEC) No 1898/87. As UDL used the name "dietary cheese" on products in which the animal fat had been completely replaced by vegetable fat, the Schutzverband believed that UDL had infringed this Regulation that stated that the name "cheese" should only be used for milk products of animal origin. The ECJ ruled that UDL's use of designations and descriptions for their products did not comply with the legal definition of milk products and concluded that using 'cheese' to designate their products may confuse and mislead consumers as to the characteristics and identity of the foodstuff. ${ }^{5}$

In 2017, the ECJ published their judgement on the Tofu Town case, case C-422/16, for which the argument was largely based on the CMO Regulation. Annex VII lists the designations reserved exclusively for milk and milk products, including the term "butter" and "cheese". Even though Tofu Town believed they were not misleading consumers with these two terms, as the packaging stated the plant-based nature of their products, the VSW interpreted it as unlawful and misleading. In their judgement, the ECJ held that the ban of using these protected terms for non-'milk products' ${ }^{6}$ still stands, even with additional explanatory designations indicating the plant-based nature of products such as 'tofu butter' or 'veggie milk'.

The ECJ stated in its ruling that the CMO Regulation clearly reserves certain terms for milk products, where 'milk' can only mean milk that is derived from animals and for which no added substance can replace, partly or fully, any milk constituents. ${ }^{7}$ Because the names reserved for milk products at all stages of marketing, such as cream, cheese, or butter are listed in Annex VII of the CMO, the Court concluded that such designations are reserved for animal products unless they are explicitly mentioned in the list of exceptions. ${ }^{8}$ Tofu Town's terms ('veggie cheese' and 'tofu butter') are not on this list and therefore are considered to be unlawful. The Court further stated in their judgement that even the presence of additional explanatory designations (e.g. tofu butter) cannot

\footnotetext{
${ }^{3}$ Case C-101/98, Union Deutsche Lebensmittelwerke GmbH (UDL) v. Schutzverband (1999).

4 Council Regulation (EEC) No $1898 / 87$ on the protection of designations used in marketing of milk and milk products, OJ L 182, 3.7.1987.

5 Case C-101/98, Union Deutsche Lebensmittelwerke GmbH (UDL) v. Schutzverband (1999).

${ }^{6}$ Point 1 and 2, Part III, Annex VII, of the CMO Regulation, supra note 6.

7 Point 2, Part III, Annex VII, of the CMO Regulation, supra note 6.

${ }^{8}$ Case C-422/16, supra note 1, at 43; Press Release No 63/17, supra note 1.
} 
completely eliminate the risk of confusing consumers. ${ }^{9}$

In the CMO, marketing standards for agricultural products are stated to be able to contribute to the improvement of economic conditions. Applying the standards is therefore seen as serving the interests of both producers and consumers. ${ }^{10}$ Furthermore, these standards contribute to the determination of fair competition, ${ }^{11}$ hence Tofu Town was judged to also infringe the German Act Against Unfair Competition (UWG), ${ }^{12}$ specifically paragraph 3 a. This paragraph states that infringement on provisions aiming to regulate market behaviour (in this case the $\mathrm{CMO}$ ) shall be seen as acting unfairly. ${ }^{13}$

\section{Implications for the dairy-alternative industry and its consumers}

The ruling on the Tofu Town case has further clarified the legal interpretation of the CMO Regulation and protected dairy terms. This legislation is expected to affect the dairy alternatives industry and its consumers both positively and negatively, as put forward in this section.

\subsection{Positive implications}

\subsubsection{Legal clarity}

The first positive effect of the ruling on the development of plantbased alternatives is the fact that it provides legal clarity to food business operators. By increasing legal clarity, regulations increase the certainty in the outlook of investments in the industry (Jacques Pelkmans, 2014; Lenssen, Bast, \& de Boer, 2018). Thus, when there is certainty that legislation will not hinder the development and marketing of products, food business operators are more likely to invest in innovation for which research and development often requires large amounts of money, and thus investors are more likely to provide funding (Jacques Pelkmans, 2014; Lenssen et al., 2018). The achievement of a level playing field for all business operators, through harmonisation of food law at the EU level, is also known to support innovation (Wijnands, Bremmers, van der Meulen, \& Poppe, 2008). The European Commission has claimed that the GFL contributed to the levelling of the playing field, which resulted in an increase of $72 \%$ of the internal food and beverage trade over the past 10 years (European Commission, 2018; Wijnands et al., 2008). In the case of the dairy industry, this legal clarity makes it explicitly clear what can be considered as a dairy product and therefore which products can and cannot make use of the protected dairy terms.

\subsubsection{Consumer protection}

Whereas before 2002, the European legal framework for foods had mainly focussed on harmonising the internal market by reducing trade barriers, after various food scares the aim of EU food law shifted towards firstly ensuring the highest level of protecting consumers' health and interests, and only secondly stimulating EU harmonisation (Szajkowska, 2009; Vos, 2000). As shown in the 2018 Fitness Check of the GFL, EU food law has been able to achieve both these goals (de Boer, 2019; European Commission, 2018). This is ascribed to the introduction and application of risk analysis methodologies. The high level of food safety achieved within the EU is globally recognised, strengthening the quality perception of EU food products in the global market (European Commission, 2018; Meulen \& J., 2010). Certain academics therefore argue that although industry perceives the EU regulatory burden as heavy, it does not necessarily negatively affect the competitiveness of food

\footnotetext{
9 Case C-422/16, supra note 1 , at 48.

10 Case C-422/16, supra note 1, at 47; Regulation (EU) 1308/2013, supra note 11, at Preamble 64.

11 Preamble (76), Regulation 1308/2013, supra note 11.

12 The German Act against Unfair Competition (Gesetz gegen den unlauteren Wettbewerb), supra note 5 .

${ }^{13}$ Case C-422/16, supra note 1 , at 14.
}

business operators in the global market, as products adhering to the European legal standards are considered to be of high quality (European Commission, 2018; Wijnands et al., 2008).

The GFL stipulates that consumers should be protected from false and misleading statements, to protect their interest. This is also addressed in other EU regulations, such as Directive 2005/29/EC on unfair business-to-consumer commercial practices, ${ }^{14}$ which makes it unlawful to provide false or deceiving information to consumers. For foodstuffs, information provision to consumers is regulated by the FIC Regulation, which further specifies the mandatory information required on food labels and menu's and other forms of food information. These regulatory measures are all aimed to fully inform consumers, to allow them to make any decision about food or food consumption (Meisterernst, 2013). Protecting consumers from misleading has also been one of the main reasons for limiting the names of dairy products to merely animal-based products, to for example ensure that consumers buying 'imitation' products cannot be mislead by differences in nutritional value from their animal-based counterparts (Leone, 2019). The Tofu Town judgement shows that the ECJ believes it is necessary to limit potential names for alternatives, to ensure that consumers can clearly distinguish products. However, research now suggests that using dairy terms on plant-based products does not mislead consumers, but rather helps those consumers who consciously look for plant-based products to identify those food items alternative to conventional dairy products (Domke, 2018; Linkage Research \& Consulting, 2019; Watson, 2018). These findings raise the question whether or not protecting dairy terms is necessary for consumer protection.

\subsection{Identified barriers}

Although the EU regulatory framework has benefitted the plantbased alternative food industry by providing legal clarity and ensuring a high level of food safety, EU food regulations can also negatively impact innovation in the industry (European Commission, 2018; Wijnands et al., 2008). The main barriers identified for developing and marketing dairy alternatives are: (i) the varying interpretation of the CMO; (ii) the different level of consumer protection between sectors; (iii) the absence of a legal definition of vegan food; and (iv) the CMO's narrow definition of 'milk' and 'milk products'.

\subsubsection{CMO interpretation}

Case law has shown the boundaries in marketing dairy alternative products through the Court's interpretation on the protection of dairy terms (Arayess \& Jeukens, 2018; van Couter, Mahy, \& d'Ath, 2016). The CMO forbids the use of dairy designations for products that do not contain milk originating from mammary secretion. However, these provisions have been interpreted and enforced differently by different national courts, as exemplified by two disputes in Belgium and the Netherlands in which Alpro, a plant-based food company, was involved (Arayess \& Jeukens, 2018; van Couter et al., 2016). In 2015, the Belgian national court decided that Alpro is not allowed to use the phrase "variation to" dairy or yoghurt, but would be allowed to use "alternative to" as it deemed that the latter was not misleading to consumers unlike the former (van Couter et al., 2016). In 2017, the Dutch Court however declared that the CMO provisions does not forbid the use of such terms to be used by Alpro in all circumstances (Arayess \& Jeukens, 2018). The Court also allowed the use of the phrase "alternative to", as this phrase cannot be qualified as using dairy terms as name or designation of the product. In this case, the use of dairy terms is considered a way to communicate that the product is a plant-based alternative to a dairy product. With this reasoning, the Court also allowed Alpro to use other

\footnotetext{
${ }^{14}$ Directive 2005/29/EC of the European Parliament and of the Council concerning unfair business-to-consumer commercial practices and the internal market. Consolidated version 28 May 2022.
} 
protected dairy terms such as "yoghurt cultures", as it merely provides information that the product contains bacterial cultures also found in yoghurt. Alpro is also allowed inform consumers that their products can be found in the yoghurt or milk section in grocery stores. Interestingly, the Dutch Court pointed out that the word "dairy" (zuivel) in itself is not a reserved dairy designation. Therefore, Alpro is allowed to use the phrase "dairy-free alternative to milk", because in this case "dairy" is not off-limits and "milk" is not used as product designation or name (Arayess \& Jeukens, 2018). Given the leniency of interpretation in one Member States versus another, this situation may serve as an opportunity in marketing plant-based alternatives in Member States such as the Netherlands.

\subsubsection{Consumer protection}

As described in literature, milk products are considered to be more regulated than meat products. This view is supported by the fact that there are more legal names for the milk products category than there are for meat (Carreño \& Dolle, 2018; Pisanello \& Ferraris, 2018). Legal names for foods can be found in Annex VII of the CMO, in which the list is structured based on the categories provided in Article 78 of this Regulation. As there are more terms for which dairy alternatives are prohibited for use, sales descriptions for plant-based alternatives for dairy are subject to more restrictions than those for fish and meat (Carreño \& Dolle, 2018). A food company has freedom in naming their product as long as there is no legally determined name (legal name). The creative role of the industry is thus recognised, whilst limited (Pisanello \& Ferraris, 2018). Legislators are obliged to apply the principle of non-discrimination to avoid that comparable situations can be treated differently. Tofu Town has raised its concerns on why food business operators who market fish or meat alternatives are not subject to the same restrictions as milk and milk products alternatives. The ECJ claimed in their judgement of case c-422/16 that the restrictions imposed on milk and milk products alternatives are not discriminatory, nor inconsistent with the principle of equal treatment: every sector defined in the CMO Regulation has its own specific features that distinguishes each sector from one another. Therefore, applying different rules for different sectors is not discriminatory, as sectors are noncomparable and thus are subject to different rules. Pisanello and Ferraris (2018) however argued that because the ban is only applicable to one supply chain, consumers are more protected in terms of dairy than fish or meat products, resulting in 'totally asymmetric' protection (Pisanello \& Ferraris, 2018).

In 2017, the Dutch Food and Consumer Product Authority (NVWA) was of the opinion that the De Vegetarische Slager, a vegan food company, was misleading consumers by using animal names such as "fish-free tuna" for their purely plant-based products (Garfield, 2017; Michail, 2017). The NVWA therefore urged the Vegetarian Butcher to change their products' labelling, an interpretation shared by the European association representing processed meat manufacturers who called for the Commission to provide similar legal protection for meat terms as dairy terms (Michail, 2017). Similarly, the French government introduced a bill to ban meat-free products from using meat terminology, following the ECJ's reasoning on the Tofu Town case (Askew, 2018). Domke (2018) however argued that such a ban may negatively affect consumers by overcomplicating the process of finding meat alternative products (Domke, 2018). When food business operators are unable to use familiar terms to convey the characteristics of a product and communicate what consumers can expect from such a product, the author argues that the process for consumers to identify plant-based meat alternatives is becoming less straightforward (Domke, 2018). These different actions raises the question whether the current CMO market sector categorisation is organised in the best way possible to meet the objectives of ensuring consumer protection and fair competition. A potential reevaluation of this categorisation by the Commission should consider these issues. Especially since products from different sectors in practice share features that are not sector-specific, with all products being plant-based and serving the purpose of substituting an animal-based product. Additionally, with these products having the same function and form as animal-derived foods, consumers may use plant-based products in a similar way and as replacement in their diet.

\subsubsection{Legal definition of vegan food}

Over the last few years, the lack of regulations for vegetarian and vegan foodstuff has been highly debated. Various stakeholders, including food business operators and consumer associations, have been voicing their need for legal clarity for these growing food categories (Carreño \& Dolle, 2018; Domke, 2018). Currently, there is no legal definition in the EU when to label a product as vegetarian or vegan food, nor are any conditions of use defined. This creates uncertainty for the industry, potentially resulting in different interpretations between Member States (Domke, 2018). This uncertainty may pose as an obstacle to product development and the free movement of goods. The legal definition of vegan foods is especially relevant for the dairy alternative industry, whose products are intended to substitute animal products whilst explicitly distinguishing themselves from the animal-based food that they aim to substitute (Fuentes \& Fuentes, 2017). The meat or dairy alternative products' main selling point is often that it is not animal based, and it is therefore in the interest of the food operator to communicate that these products are purely plant-based (Domke, 2018; Michail, 2016). The limited ability to communicate the food's characteristics and to inform upon what consumers can expect from this type of product (regarding i.e. taste, texture, as well as the product's intended purpose), without such statements being considered misleading, may therefore result in a barrier to innovation and communication.

In 2011 already, the need for legal clarity with regard to vegan and vegetarian food was acknowledged by the Commission (Domke, 2018; Pisanello \& Ferraris, 2018). Under Article 36(3)(b) of the FIC Regulation, the Commission is obligated to develop and adopt an implementing act on 'information related to suitability of a food for vegetarians or vegans', even though no deadline is provided (Domke, 2018). In 2016, the German Consumer Protection Ministers unanimously voted for a decision on how to define vegan and vegetarian products. This prompted the German Federal government to urge the Commission to act upon FIC's Article 36 (Carreño \& Dolle, 2018). Still, no EU-wide agreement on these definitions has been reached, despite the proposal for the FIC had already included such definitions that were later removed from the Regulation's final version (Carreño \& Dolle, 2018). At the same time, the International Organization for Standardization (ISO) together with national organisations for standardisation, is currently developing a standard for "food suitable for vegetarians/vegans" (International Organization for Standardization, 2019). In 2018, the Commission announced plans to develop EU-wide definitions in 2019 (European Commission, 2017).

Clear-cut definitions are of interest to both consumers and the industry, as this can reduce uncertainty on what it means when foods are labelled as vegan, thereby also addressing the issue of plant-based alternatives to animal products. Theoretically, such a legal definition could be used in conjunction with a dairy term to describe (not to name or designate) a plant-based product, to convey the true nature of the food. This could eliminate any risk of misleading, when there is consensus that vegan food does not contain animal ingredients. In this sense, the ECJ's concerns over using names such as "veggie cheese" by Tofu Town to be misleading, would be resolved if it were to be changed to "vegan cheese".

\subsubsection{The narrow definition of milk and milk products}

The fourth identified potential barrier to innovation in the dairyalternative industry is how legislators and enforcement authorities interpret the concept of 'misleading'. Article 16 of the GFL describes that food labelling shall not be misleading to consumers, with FIC Article 7 elaborating what is considered to be fair food information practices (Domke, 2018). In the case of dairy alternatives, food business operators 
are at risk of being considered misleading when naming and marketing their products to be dairy alternatives (Carreño \& Dolle, 2018). With milk products and terminology explicitly defined and their terminology exclusively reserved in the $\mathrm{CMO}$, the interpretation of these provisions in case law regarding dairy terms are overall strict, literal, and with no exceptions unless these are explicitly mentioned in the Commission Decision 2010/791/EU (Bolton, 2017; Pisanello \& Ferraris, 2018). As discussed above however (section 3.2.2), interpretation of national courts of Member States has been inconsistent.

The protection of dairy terms such as milk or yoghurt were established to prevent consumers being misled by confusing a product to contain animal-derived milk, as put forward in section 3.1.2. However, it can be questioned whether consumers are actually confused by these terms: consumers have been shown to associate these protected dairy terms with purely plant-based products as well, and have been shown to use these terms to look for and identify plant-based alternatives to conventional dairy products (Domke, 2018; Watson, 2018). US research showed 3 in 4 consumers to be in favour of allowing plant-based foods to use dairy terminology (with only $13.5 \%$ of the 7000 respondents wanting to exclusively reserve this for animal-based products) (Linkage Research \& Consulting, 2019). Another study showed that 75\%-78\% of consumers understand that plant-based milk products do not contain cow milk and believe that "milk" is the most appropriate name for dairy alternatives such as soy milk (Watson, 2018).

Although these consumer studies were conducted in the US, a similar discussion is currently taking place in the EU. The findings of these studies give rise to the question what purpose the protection of these terms serves when consumers are not misled by these designations? The initial objective of such protection may have been to prevent misleading practices. However, today "imitation food" such as "analogue cheese" are purposely developed to look and taste as identical as possible to traditional animal-based products for consumers that actively look for plant-based substitution products (Bailey, 2018; Carreño \& Dolle, 2018). It may thus be questionable whether or not the ECJ's claim that the use of protected dairy names for plant-based products can be confusing to consumers, holds true. Research with European consumer studies could show whether or not European consumers are misled by plant-based products that make use of dairy terms. When such studies demonstate that consumers are misled, the current provisions on protected dairy terms may be considered justified. However, if they confirm that consumers are not misled by these terms, revision of the current protective regulations may be justified. Still, the use of protected dairy terms on plant-based products should only be for the purpose of communicating the products' intended function and physical characteristics, and not to claim or suggest that the products contain comparable nutritional profiles if this is not necessarily the case.

\subsection{Decreasing barriers}

As put forward above, the current ban on dairy names for plant-based alternatives highly affects innovation within these product segments. Various solutions have been put forward to deal with these identified barriers. Firstly, to simplify the process for consumers to find meat alternative products, the Commission may re-evaluate the current organisation of market sectors in the CMO. It should be taken into account that products from different sectors in practice share non-sectorspecific features: both plant-based dairy and meat alternative products are mainly or exclusively derived from plants, and are functionally equivalent for consumers. Another suggestion is to adopt an EU wide legal definition of vegan food, to end any uncertainty on which concepts these terms cover. These legal definitions may eliminate the risk of misleading consumers with plant based products: when 'vegan' is clearly defined and is used in conjunction with a dairy term, this confirms the product contains no animal ingredients (e.g. animal milk). Furthermore, amending the CMO regarding existing provisions on the protection of dairy terms, or extending the list of exceptions for plant-based products that are allowed to use dairy terms, are two other options to accommodate the legal framework to market demands.

When deciding to make such legal changes, the Commission is obliged to also take other factors into consideration, including economic and ethical considerations. Given that dairy is the second biggest agricultural sector in the EU, there is significant economic interest in the sector (Augère-Granier, 2018). The Commission therefore has the difficult task of balancing the competing interests of the dairy and dairy alternative industries when considering this issue. The potential adjustments suggested above with regards to the dairy terms dilemma may therefore not be realised in a short time frame.

Amending the list of exceptions under Decision 2010/791/EC depends on Member States. Foodstuffs listed in this decision are exempted from the provisions on the protection of dairy terms as they are accepted by the Member States as either: (i) products that consumers are familiar of due to traditional use; and/or (ii) the protected dairy terms are clearly used to only describe the product's characteristic, ${ }^{15}$ and therefore the use of dairy terms will not mislead the consumer. The Commission is empowered to adopt implementing acts establishing this list of products, which shall be based on Member States' indicative lists of products. Member States are herewith given the opportunity to add new products that are allowed to use protected dairy terms within their territory.

\section{Conclusions and future perspectives}

This paper highlights that whilst the ECJ ruling in the Tofu Town case provides legal clarity and the EU legal framework could protect consumers from misleading practices by protecting dairy names for animal-based products, current legislation can also negatively affect innovation for dairy alternatives. Both (i) legally defining vegetarian and vegan food at the EU level, and (ii) either amending milk (products) definition in the $\mathrm{CMO}$, or expanding the list of exceptions, could serve in improving the legal framework to allow for innovation. The Commission is empowered to amend the CMO or the list of exceptions if there are demonstrated needs to do so based on evolved consumer demands. However, with dairy being the second biggest agricultural sector in the $\mathrm{EU}$, the Commission must balance the competing interests of the dairy and dairy alternative industry.

Member States play a key role in expanding the list of exceptions to the CMO provisions. If there is sufficient demand or a strong consensus within a Member State, that certain dairy alternative products should be exempted from the dairy term restrictions, this terminology may be suggested in a Member State's list. Consumer studies resembling those conducted in the US can justify such suggestions. Also the Severi case, ${ }^{16}$ where the ECJ stated that the length of time for which a name has been used for a product may affect the expectation of the reasonable consumer, can be used as one of the factors to take into account when assessing whether a food label may be misleading. ${ }^{17}$ Further research will be necessary to provide insights into consumer perception regarding the use of dairy terms on growing market of plant-based alternatives.

\section{Declaration of competing interest}

The authors declare the following financial interests/personal relationships which may be considered as potential competing interests: Annisa Leialohilani was still employed at Upfield Research and Development B.V., the Netherlands, during the duration of the research.

\footnotetext{
15 Point 5, Part III, Annex VII of the CMO.

16 C-446/07, Alberto Severi v Regione Emilia Romagna (Severi) [2009] ECR I08041, para. 62 .

17 Schutzverband (1999)
} 


\section{Acknowledgments}

The authors thank Paul Whitehouse and Carlo Bulkmans who provided valuable insights and discussions that greatly improved the manuscript. This research was made possible with the support of the Dutch Province of Limburg, who had no role in conducting nor describing the research presented in this manuscript.

\section{References}

Arayess, S., \& Jeukens, F. (2018). The Netherlands • Alpro's dairy alternatives: What is allowed and what is not in the light of ECJ's TofuTown? European Food and Feed Law Review, 13(1).

Askew, K. (2018). France bans use of meaty names for veggie food. Food Navigator.

Augère-Granier, M.-L. (2018). The EU dairy sector: Main features, challenges and prospects.

Bailey, T. (2018). Dare not to dairy. Retrieved from https://services.rabobank.com/ publicationservice/download/publication/token/tRJL6VMr6xTTT5eFd6m0.

de Boer, A. (2019). Scientific assessments in European food law: Making it future-proof. Regulatory Toxicology and Pharmacology, 108, 104437. https://doi.org/10.1016/j. yrtph.2019.104437.

Bolton, B. (2017). Dairy's monopoly on words the historical context and implications of the $<$ em $>$ TofuTown $</$ em $>$ decision. European Food and Feed Law Review, 12(5), $422-430$.

Carreño, I., \& Dolle, T. (2018). Tofu steaks? Developments on the naming and marketing of plant-based foods in the aftermath of the TofuTown judgement. European Journal of Risk Regulation, 9(13), 575-584.

Chalupa-Krebzdak, S., Long, C. J., \& Bohrer, B. M. (2018). Nutrient density and nutritional value of milk and plant-based milk alternatives. International Dairy Journal, 87, 84-92. https://doi.org/10.1016/j.idairyj.2018.07.018.

Court of Justice of the European Union. (2017). Press Release No 63/17. Judgment in case C-422/16.

van Couter, Y., Mahy, A., \& d'Ath, F. (2016). Belgium • Ceci n'est pas du lait - this is not milk. European Food and Feed Law Review, 11(4).

Department for Environment Food and Rural Affairs. (2017). Guidance: Naming food products.

Domke, F. (2018). Vegetarian and vegan products - labelling and definitions. European Food and Feed Law Review, 13(2).

Euromonitor International. (2017). From almond to pea: The growing appetite for plantbased milk.

European Commission. (2017). Regulatory fitness and performance programme (REFIT) and the 10 priorities of the commission. Brussels.

European Commission. (2018). Fitness Check of general food law.

European Parliament and Council. (2010). 2010/791/EU: Commission Decision of 20 December 2010 listing the products referred to in the second subparagraph of point III(1) of Annex XII to Council Regulation (EC) No 1234/2007 (notified under document C(2010) 8434) (2010). Orkesterjournalen L, 336, 55-59. https://doi.org/ $10.3000 / 17252555 . L 2010.336$.eng, 21.12.2010, p. 55. Official Journal of the European Union, L 336, 21 December 2010, 53.

European Parliament and Council. (2011). Regulation (EU) No 1169/2011 of the European Parliamanent and Council of 25 October 2011 on the provision of food information to consumers (2011). Official Journal, L304, 18-63. https://doi.org/ 10.3000/19770677.L 2011.304.eng, 22.11.2011, pp. 18-63. Official Journal of the European Union, $L$ 304, 22 November 2011, 54.

European Parliament and Council. (2013). Regulation (EU) No 1308/2013 of the European Parliament and Council of 17 December 2013 establishing a common organisation of the markets in agricultural products (2013) Official Journal, L347 20, 671-854. https://doi.org/10.3000/19770677.L_2013.347.eng, 12.2013, pp. 671-854. Official Journal of the European Union, L 347, 20 December 2013, 56.

Food Standards Agency. (2014). Food information regulations 2014: Summary guidance for food business operators and enforcement officers in Scotland, Wales and Northern Ireland. Retrieved from https://www.food.gov.uk/sites/default/files/medi a/document/fir-guidance2014.pdf.

Fuentes, C., \& Fuentes, M. (2017). Making a market for alternatives: Marketing devices and the qualification of a vegan milk substitute. Journal of Marketing Management, 33 (7-8), 529-555. https://doi.org/10.1080/0267257X.2017.1328456.
Garfield, L. (2017). This vegetarian butcher shop sells fresh steaks and chicken - but it doesn't slaughter any animals. Business Insider. Retrieved from https://www. businessinsider.com/in/This-vegetarian-butcher-in-the-netherlands-2015-11?intern ational=true \& $\mathrm{r}=\mathrm{US} \& \mathrm{IR}=\mathrm{Tshop}$-sells-fresh-steaks-and-chicken-but-it-doesnt-slaugh ter-any-animals/articleshow/61425739.cms.

International Organization for Standardization. (2019). ISO/CD 23662 Food suitable for vegetarians/vegans. Retrieved December 3, 2019, from https://www.iso.org/ standard/76574.html.

Jacques Pelkmans, A. R. (2014). Does EU regulation hinder or stimulate innovation? CEPS Special Report, 96.

Jeske, S., Zannini, E., \& Arendt, E. K. (2017). Evaluation of physicochemical and glycaemic properties of commercial plant-based milk substitutes. Plant Foods for Human Nutrition, 72(1), 26-33. https://doi.org/10.1007/s11130-016-0583-0.

Lenssen, K. G. M., Bast, A., \& de Boer, A. (2018). Clarifying the health claim assessment procedure of EFSA will benefit functional food innovation. Journal of Functional Foods, 47, 386-396. https://doi.org/10.1016/j.jff.2018.05.047.

Leone, L. (2019). Nomen est omen: On the legal identity of dairy alternatives in the USA. European Food and Feed Law Review, 14(5), 436-444.

Linkage Research, \& Consulting. (2019). Consumers support use of dairy terms for plantbased foods. Retrieved from https://linkageresearch.com/fda-plant-based/.

Mäkinen, O. E., Wanhalinna, V., Zannini, E., \& Arendt, E. K. (2016). Foods for special dietary needs: Non-dairy plant-based milk substitutes and fermented dairy-type products. Critical Reviews in Food Science and Nutrition, 56(3), 339-349. https://doi. org/10.1080/10408398.2012.761950.

Meisterernst, A. (2013). A new benchmark for misleading advertising. European Food and Feed Law Review, 8(2), 91-96. Retrieved from http://www.jstor.org/stable/ 24325911.

Meulen, B., \& J, B. M. (2010). The function of food law. On objectives of food law, legitimate factors and interests taken into account.

Michail, N. (2016). German court rules against "vegan cheese" - but what should plant-based alternatives be called? (Vol. 2019), 2019. Retrieved from https://www.nutraingred ients.com/Article/2016/04/29/German-court-rules-against-vegan-cheese-but-whatshould-plant-based-alternatives-be-called.

Michail, N. (2017). Vegetarian Butcher slams Dutch food authority for double standards over "misleading" meat name ban. Retrieved from https://www.foodnavigator.com/ Article/2017/10/05/Vegetarian-Butcher-slams-Dutch-food-authority-for-double-sta ndards-over-misleading-meat-name-ban.

Munekata, P. E. S., Domínguez, R., Budaraju, S., Roselló-Soto, E., Barba, F. J., Mallikarjunan, K., et al. (2020). Effect of innovative food processing technologies on the physicochemical and nutritional properties and quality of non-dairy plant-based beverages. Foods, 9(3), 288. https://doi.org/10.3390/foods9030288.

Pisanello, D., \& Ferraris, L. (2018). Ban on designating plant products as dairy: Between market regulation and over-protection of the consumer. European Journal of Risk Regulation, 9(1), 170-176. https://doi.org/10.1017/err.2018.4.

Röös, E., Garnett, T., Watz, V., \& Sjörs, C. (2018). The role of dairy and plant based dairy alternatives in sustainable diets. Uppsala: Sverige. Retrieved from https://pub.epsilon. slu.se/16016/.

Sansone, J. (2017). Dairy farmers lobby for ban on soy and almond drinks being called "milk". Advances in Dairy Research, 5(4). https://doi.org/10.4172/2329888x.1000197. Retrieved from https://www.abc.net.au/news.

Sousa, A., \& Bolanz, K. A. K. (2017). (2017-05-04/truth-labelling-plant-based-milkalternatives-soy-almond/8494614). Nutritional Implications of an Increasing Consumption of Non-Dairy Plant-Based Beverages Instead of Cow's Milk in Switzerland.

Strecker, T. (2016). Developments in European food law: What is vegetarian? European Food and Feed Law Review, 11(1).

Szajkowska, A. (2009). From mutual recognition to mutual scientific opinion? Constitutional framework for risk analysis in EU food safety law. Food Policy, 34(6), $529-538$.

Vos, E. (2000). EU food safety regulation in the aftermath of the BSE crisis. Journal of Consumer Policy, 23(3), 227-255. https://doi.org/10.1023/A:1007123502914.

Watson, E. (2018). Does almond milk contain cow's milk? Not sure, say $16 \%$ of Americans, yes, say 9\%, No, say 75\%. Retrieved from https://www.foodnavigator-u sa.com/Article/2018/10/12/Does-almondmilk-contain-cow-s-milk-Not-sure-say16-of-Americans-Yes-say-9-No-say-75FoodNavigator-USA.

Wijnands, J. H. M., Bremmers, H. J., van der Meulen, B. M. J., \& Poppe, K. J. (2008). An economic and legal assessment of the EU food industry's competitiveness. Agribusiness, 24(4), 417-439. https://doi.org/10.1002/agr.20167. 